\title{
1. Variable geometry and differentiation as structural features of the EU legal order
}

\section{Bruno De Witte}

\section{INTRODUCTION: FROM ANOMALY TO A STRUCTURAL FEATURE OF EU LAW}

Until the adoption of the Treaty of Maastricht, there was a growing sense of the unity of a single integrated Community legal order, despite the existence of three different Communities. That unitary legal order was also uniformly applicable to all the Member States, except for some limited derogations provided by primary or secondary law, which exempted single countries from specific rules of Community law. The Court of Justice set great store on this uniform application. For example, in a judgment of 1972, it held that:

[T]he attainment of the objectives of the Community requires that the rules of Community law (...) are fully applicable at the same time and with identical effects over the whole territory of the Community without the Member States being able to place any obstacles in the way. ${ }^{1}$

This ambition of uniform application was backed by the duty for national courts to apply directly effective EC law and by the infringement actions the Commission could launch against non-complying Member States. However, there were also inherent limits to this aspiration of uniform application. The main limit was, and is, that EU law is applied most of the time by national authorities and courts that do not actually apply EU law faithfully and correctly on many occasions. But there was another limit, inherent in Community law itself; namely the fact that there were

1 Case 48/71 Commission v Italy, ECLI:EU:C:1972:65, para. 8 (emphasis added). 
forms of European law and policy that contained an inherent permission for differential application. The most obvious example is the fact that directives could be transposed by the Member States with the freedom to decide the 'form and methods' of that transposition and further application (as the current Article 288 TFEU still holds).

Nevertheless, those instances of territorially-based differential application of EC law could be seen as anomalies which would be gradually eliminated by the further development of the Community legal order. This is, quite clearly, no longer the dominant perception today. Not only is the gap between the goal of uniform application and the messy practice within the Member States now accepted as an unavoidable feature of the multilevel nature of the application of EU law, but the EU legal order itself has gradually moved away from the ideal of unity and now accommodates various forms of uneven application across its Member States, whereby these states are allowed to derogate from the common norms, or, more radically, they are allowed not to participate in the making of EU law norms and are consequently not bound to apply those norms either. The latter form of differentiation is sometimes called variable geometry, pointing to the fact that the territorial design of a certain EU policy is modified from the outset, due to the absence of some Member States.

Strong functional and normative reasons explain this evolution and make it very likely that this complex regime of differentiation is here to stay and probably to expand further. The functional reason is that variable geometry has proved essential for allowing European integration to proceed. Widening, deepening and uniformity could not go together. The choice for widening-with-deepening of the integration process, a choice that was repeatedly made in the past 25 years of the EU's existence, led to sacrificing the aspiration to a uniform legal order. But differentiation is also normatively attractive since it allows for the diverse preferences of national governments and national public opinions to be accommodated. Some countries can decide to move ahead with the European integration process in a given field without being stopped by the more reluctant countries, but also without forcing the latter to participate in new cooperation ventures.

A wide variety of forms of differentiation currently exist, and some policy areas are more clearly marked by their use than others. At the introductory stage of this volume, a rapid panorama will be offered, based on a simple distinction between the mechanisms of differentiation laid down in the Treaty text, and which therefore have a formal constitutional status (section 2), and the forms of differentiation that were developed beyond the text of the Treaties, through the practice of the EU 
institutions and the Member States (section 3). To this picture of internal differentiation, one should add the numerous examples of external differentiation, whereby third countries are associated with the adoption and application of EU law. ${ }^{2}$

\section{FORMS OF DIFFERENTIATION IN THE TREATY TEXT}

\subsection{The Gradual Spread of Opt-outs}

The Single European Act introduced a potential mechanism of differentiation at the heart of Community law, namely the single market, by creating a complex procedure allowing for country-specific environmental derogations from internal market harmonization in what was then Article 100a EEC (the current Article 114 TFEU). At the time, the new mechanism was criticized for disrupting the unitary ethos of the common market, but it was, in fact, rarely invoked by the Member States. Moreover, the Commission, helped by the Court's case law, kept a tight control on the potential for country-specific derogations which was opened up. The new mechanism, which is still included in the TFEU, albeit in modified form, proved to be a useful safety valve allowing the Member States to pursue more progressive environmental policies, rather than a Trojan horse within internal market law. ${ }^{3}$

The Treaty of Maastricht innovated by allowing some Member States not to participate at all, or in limited ways, in crucial areas of Community law such as Economic and Monetary Union (EMU). The major advance in the scope of activity of the EC/EU, brought about by the Maastricht Treaty, had to be paid for by abandoning the notion of a unitary Community legal order that applied evenly in all its Member States. Instead, new mechanisms were put in place allowing some countries not to participate in the development of Community law in certain areas and, consequently, not to be bound by that Community law either. This new institutional complexity was noted at the time and criticized by many observers. ${ }^{4}$

This structural differentiation was a functional necessity to allow the Treaty of Maastricht to be adopted in the first place. The urge to

\footnotetext{
2 See the chapter by Ott in this volume.

3 See the chapter by Vos and Weimer in this volume.

4 Most famously by Deirdre Curtin, 'The Constitutional Structure of the Union: A Europe of Bits and Pieces' (1993) 30 Common Market Law Review 17.
} 
neutralize the obstructive power of single countries (that is, their power to prevent the others from deepening their cooperation) had become very acute during the twin intergovernmental conferences (the EMU and EPU conferences) that eventually led to the Treaty of Maastricht. Until the very end, the United Kingdom (UK), in particular, opposed essential elements of the package that the other countries came to support, namely the creation of the EMU and the rather less spectacular plan to transfer new competences in social policy. In both cases, a compromise was brokered at the very final stage of the negotiations, and this was indeed crucial to reaching the final agreement on the text of the Treaty. ${ }^{5}$ In the case of EMU, an opt-out was agreed to for the UK but also for Denmark; this opt-out was presented as temporary, although no timeline was laid down for those countries to join the EMU. As regards social policy, the legal construction was seemingly the opposite, as the Maastricht Treaty comprised a Protocol by which all the Member States enabled 11 of them (that is, all members except the UK) to opt-in to a separate Social Policy Agreement laying down new competences in the field of social policy. Both stratagems had one major element in common: they allowed for the creation of new norms of secondary EC law that would be adopted by the Council in a reduced composition, but with the participation of the other institutions acting in their normal composition and resulting in EC law that had all the qualities of 'normal' EC law, except that it did not apply in the dissenting Member States. The Maastricht Treaty thus set the legal model for the way in which variable geometry is still practised today: structural differentiation exists between Member States both at the time of law making and at the time of its application. The Maastricht Treaty also set the tone for the legal modelling of Treaty opt-outs: they tend not to be very visible in the main text of the Treaties, but they are half-hidden in annexed Protocols and Agreements. The Treaty of Maastricht was accompanied by 17 Protocols, eight of which contained country-specific derogations of one kind or another. ${ }^{6}$

5 The compromise on social policy, in particular, was only achieved at the Maastricht Summit itself. See Derek Beach, The Dynamics of European Integration: Why and When EU Institutions Matter (Palgrave Macmillan 2005) 100, and Giorgio Maganza, 'Jean-Claude Piris, un seul homme pour cinq traités' in A Man for all Treaties - Liber Amicorum en l'honneur de Jean-Claude Piris (Bruylant 2012) 407, who evokes a draft being written in the cafeteria of the provincial government building in Maastricht, where the Summit took place.

6 Isabelle Bosse-Platière, 'Annexes aux Traités européens et différenciation', in Ségolène Barbou des Places (ed.), Aux marges du traité: déclarations, protocoles et annexes aux traités européens (Bruylant 2011) 115, 117. 
Since Maastricht, opt-outs have multiplied and have become a major feature of the EU legal order. The Amsterdam Treaty 'repatriated' the Schengen regime within the legal order of the European Union, ${ }^{7}$ but the price that had to be paid for this move - given the lack of unanimous support among all Member States - was a new opt-out Treaty regime for the UK and Ireland, and another one for Denmark. ${ }^{8}$ A system of differentiation between EU Member States that had existed outside the EU legal framework was thus brought inside that framework, but without modifying the degree and content of the differentiation and creating, indeed, a number of frictions in the institutional functioning of the EU's immigration and border control policies. ${ }^{9}$ This vast new opt-out area established by the Amsterdam Treaty joined the Maastricht-based opt-out regime for the EMU. It 'replaced', so to speak, the social policy opt-out which was terminated at Amsterdam in view of the fact that the Labour government, which had recently come to power in the UK, had agreed to join the other Member States in their post-Maastricht regime of social policy law making.

Interestingly, the Convention on the Future of the Union of 2002-3, despite its general ambition to simplify and consolidate the existing

7 That regime was laid down in the Protocol integrating the Schengen acquis into the framework of the European Union, annexed by the Treaty of Amsterdam to the EC and EU Treaties. That Protocol was somewhat modified by the Treaty of Lisbon and has now become Protocol No 19 annexed to the Treaties.

8 As Monar put it, in the title of his analysis of the new mechanism, the Amsterdam Treaty had achieved 'reform at the price of fragmentation' (Jörg Monar, 'Justice and Home Affairs in the Treaty of Amsterdam: Reform at the Price of Fragmentation' (1998) 23 European Law Review 320). For a detailed analysis of the post-Amsterdam opt-out regime, see Georgia Papagianni, 'Flexibility in Justice and Home Affairs: An Old Phenomenon Taking New Forms' in Bruno De Witte, Dominik Hanf and Ellen Vos (eds), The Many Faces of Differentiation in EU Law (Intersentia 2001) 101.

9 The special position of those countries was laid down partly in special Protocols applying to them (known today, after the Lisbon Treaty, as Protocols No 21 and 22 annexed to the Treaties) and partly in special provisions within the Schengen Protocol (No 19). On the ultra-complex legal position of the opt-out countries in relation to the Schengen acquis, see Julian Schutte, 'UK v EU: A Continuous Test Match' (2011) 34 Fordham International Law Journal 1346. For an example of the institutional frictions caused by the Schengen opt-out, see the judgment of the Court of Justice in Case C-482/08, United Kingdom v Council, ECLI:EU:C:2010:631, as to whether a contested measure came within the development of the Schengen acquis (in which the UK does not take part) or within the field of police cooperation (in which the UK fully participated at the time). 
constitutional law of the EU, did not seriously attempt to absorb the existing opt-out mechanisms. They were kept practically intact in the Constitutional Treaty, first, and in the Lisbon Treaty later. In the end, the Lisbon Treaty even added a major new opt-out regime in the field of police cooperation and criminal justice where, in return for the adoption of the 'Community method' within that policy area, the UK obtained an opt-out from future developments and even a right to unilaterally pull out from existing third pillar instruments by which the UK was bound. As before, in Maastricht and in Amsterdam, the creation of a new opt-out regime in Lisbon was a deal-making bargain without which the Lisbon Treaty would not have seen the light. ${ }^{10}$

The UK's right to pull out from its existing obligations under the former Third Pillar was a constitutional novelty, since, for the first time in the EU's history, it allowed a Member State to free itself from existing EU law obligations. The right had to be exercised in relation to all existing third pillar instruments taken together, hence the commonly used expression of a block opt-out. It was not to be exercised immediately upon the entry into force of the Lisbon Treaty, but 'at the latest six months before the expiry of the transitional period' of five years. ${ }^{11}$ Despite many misgivings expressed on the home front, ${ }^{12}$ the UK government decided to make use of that block opt-out option and duly notified the Council of this on 24 July 2013, well before the expiry of the transitional period. On 27 November 2014 (four days before its expiry), the Council adopted a Decision setting out the 'consequential and transitional arrangements' deriving from the UK's pull-out. However, on 1 December 2014 (on the fifth anniversary of the Lisbon Treaty), both the Commission and the Council adopted Decisions allowing the re-entry of the UK to a selected number of pre-Lisbon third pillar measures (35 all together, including the European Arrest Warrant, Europol and Eurojust). ${ }^{13}$ Indeed, the privileged treatment which the UK had meted out to itself

10 David Phinnemore, The Treaty of Lisbon - Origins and Negotiation (Palgrave Macmillan 2013) 164-7.

11 Protocol No 36 on Transitional Provisions, OJ 2008, C115/322, Art. 10(4).

12 See in particular the Report of the European Union Committee of the House of Lords, 'EU police and criminal justice measures: The UK's 2014 opt-out decision' (2012-13, HL 159).

13 See respectively OJ L343/11, L345/1 and L345/6. For a short discussion of what happened, legally speaking, on those days of November and December 2014, see Steve Peers, 'The UK Opts back in to the European Arrest Warrant and other EU Criminal Law' (2014) EU Law Analysis, http://eulaw analysis.blogspot.co.uk. 
when signing the Lisbon Treaty consisted not only of having a block exit option, but also a selective re-entry option for those EU measures that it liked to keep - namely the ones that seemed most useful from the point of view of the UK's domestic justice and home affairs policy. The re-entry option depended, according to the Transitional Protocol, on decisions by the Commission (for most matters) or the Council (for the Schengen-related police cooperation measures), but the EU institutions happily obliged and let the UK continue to participate in as many former third pillar measures as it wished. Note, however, that the UK's 'revolving doors' operation came at a price: the third pillar EU acts by which the UK still accepts it is bound are, since 1 December 2014, subject to the normal enforcement powers of the Commission and to the normal jurisdictional powers of the Court of Justice. ${ }^{14}$

\subsection{The Slow Development of Enhanced Cooperation}

The institutional asymmetries created by the Maastricht Treaty in the fields of EMU and social policy were presented at the time as, possibly temporary, exceptions and were not vindicated as a new structural way of addressing the problem of 'unity in diversity' in European integration. Not long after the entry into force of the Maastricht reforms, however, the debate on the constitutional codification of a general regime of 'flexibility' or 'variable geometry' began rather abruptly with a series of speeches and papers presented by leading politicians in the summer of 1994. Right from the start, this debate was linked to enlargement, flexibility being seen in some quarters as a means of sidelining unknown and possibly unpredictable newcomers. However, the debate was also linked, more immediately and pressingly, to the fear of irreconcilable differences of views between the existing Member States. In his William and Mary Lecture given in Leiden in September 1994, John Major, the then British Prime Minister, welcomed the enlargement of the EU to the east and stated that the continuing growth in size and diversity of the Union should lead to greater à la carte flexibility, whereby overlapping groups of countries would be allowed to cooperate in specific fields of common interest outside the main EU institutional framework. ${ }^{15}$ Around the same time, other countries, particularly France and Germany, started canvassing the alternative idea of enabling a stable core group of countries to cooperate across a broad range of policy fields, either within

\footnotetext{
14 Protocol No 36 (n. 11), Art. 10(1) and (3).

15 John Major, 'Europe, A Future that Works' (William and Mary Lecture, Leiden Town Hall), Agence Europe, No 6312, 10 September 1994.
} 
or outside the institutional framework of the EU. In particular, the so-called Lamers-Schäuble paper presented by the CDU-CSU fraction of the Bundestag, while never put forward as official German government policy, became a key document in this political debate, as it canvassed the idea of a core Europe (Kerneuropa) composed of a 'pioneer group' of countries. ${ }^{16}$

As a result of those debates in 1994, most governments saw both options (à la carte cooperation outside the EU framework and a structured core group either inside or outside) as threats to the cohesion of the EU and to the principle of uniform rights and duties of states, which was still seen as a central principle of the EU regime despite the opt-outs that were agreed in the Maastricht Treaty. The consensus emerging from the 1996 Intergovernmental Conference (IGC), after long and extenuating negotiations, was that some general mechanism of institutional flexibility could be put in place, but it would be encapsulated within the existing EU framework and made subject to rather strict conditions. ${ }^{17}$ Agreement was eventually reached, in the Treaty of Amsterdam, on a very cautious institutional experiment whereby a group of 'willing' states would be able to undertake closer cooperation among themselves, while using the institutional mechanisms of the EU, but, crucially, this could only be successful if the others would allow them to do so. ${ }^{18}$ Therefore, this was neither à la carte cooperation nor the creation of a fixed vanguard group. Indeed, according to one observer:

[M] uch of the debate about flexibility during the IGC focused on a set of regulatory conditions which were designed to prevent the creation of a directoire or an avant garde group which would forge ahead towards deeper integration, leaving behind those which were either not willing or not able. ${ }^{19}$

In fact, the conditions for closer cooperation imposed by the Amsterdam Treaty were so rigid that, only one year after the Treaty's entry into force,

16 CDU/CSU Group in the Bundestag, Reflections on European Policy, 1 September 1994.

17 For a political analysis of the negotiation of the Amsterdam flexibility regime, see Alexander Stubb, Negotiating Flexibility in the European Union. Amsterdam, Nice and Beyond (Palgrave Macmillan 2002) Ch. 4.

18 For a legal analysis of the original Amsterdam rules, see, among others, Helmut Kortenberg [a pseudonym], 'Closer Cooperation in the Treaty of Amsterdam' (1998) 35 Common Market Law Review 833; Giorgio Gaja, 'How Flexible is Flexibility under the Amsterdam Treaty?' (1998) 35 Common Market Law Review 855.

19 Stubb (n. 17) 49. 
and before the new regime had even been tested in practice, the Member State governments started a process of reviewing and, ultimately, redrafting the relevant rules during the IGC that led to the Nice Treaty. The substantive and procedural conditions for launching an enhanced cooperation project were later softened again by the Treaty of Lisbon, ${ }^{20}$ and the general regime of enhanced cooperation has finally been used several times in the past few years. A first and rather uncontroversial application dealt with conflicts of law on divorce. More controversial applications related to the new EU patent system and the financial transaction tax, and the legal challenges to which those initiatives gave rise, allowed the Court of Justice to give guidance on the interpretation of the conditions for recourse to enhanced cooperation. ${ }^{21}$ In particular, the Court confirmed that enhanced cooperation could indeed be used to circumvent the veto power possessed by small groups of states in areas where the TEU and TFEU continue to require unanimity in the Council. This feature of enhanced cooperation, in particular, would seem to suggest its more frequent use so as to overcome the unanimity lock; however, such side-lining of recalcitrant states goes against the grain of the Council's decision-making culture, which is still marked by the search for overall consensus among all national delegations. This could help to explain why enhanced cooperation remains, for now, a rather rarely used instrument of differentiation - despite the high hopes put in it ever since its 'invention' during the Amsterdam IGC. The painfully slow process for the enactment of a financial transaction tax directive is testimony to the fact that cooperation between states, even when formally 'enhanced', can remain substantively problematic. ${ }^{22}$

Apart from relaxing the conditions for the use of the general enhanced cooperation regime, the Lisbon Treaty put in place two policy-specific mechanisms of enhanced cooperation. During the Convention on the European Constitution, much attention was devoted to the question of facilitating closer cooperation in the field of CFSP and particularly defence. Whereas the latter policy field was previously off limits for closer cooperation initiatives, it has now been turned into a privileged area for experimentation with a range of flexibility regimes, denoting a greater acceptance of the EU as a policy-making venue for military

20 See the chapter by Peers in this volume, tracing the changes made with each Treaty revision.

21 See, ibid.

22 On this particular enhanced cooperation project, see the chapter by Devroe and Van Cleynenbreugel in this volume. 
matters. ${ }^{23}$ The post-Lisbon developments have not, however, concretized these possibilities offered by the Treaty text, since no attempts at setting up 'permanent structured cooperation' within the EU's defence policy have been made. On the contrary, we saw new instances of ad hoc coalitions, patchy multilateralism and bilateral ententes, ${ }^{24}$ such as the Lancaster House agreements concluded between France and the UK in November 2010. ${ }^{25}$

Another specific regime of enhanced cooperation created by the Lisbon Treaty, which was less prominently discussed in its preparatory phase, but proved to be more important in practice, concerns the field of economic governance, where it was grafted upon the existing variable geometry between euro-area and non-euro-area countries. The legal basis allowing for the adoption of euro-area specific legislation on economic governance (Article 136(1) TFEU) was used for important parts of the 'six-pack' and 'two-pack' economic governance reforms; ${ }^{26}$ and, more recently, unprecedented forms of variable geometry were experimented with for banking supervision, where the new ECB-centred mechanism, while legally mandatory only for euro-area states, is opened up for 'closer cooperation' with non-euro states who wish to join. ${ }^{27}$

23 See, for an analysis of the Lisbon changes in this policy area, Marise Cremona, 'Enhanced Cooperation and the Common Foreign and Security and Defence Policy' (2009) EUI Working Papers LAW 2009/21; Hervé Bribosia, 'Les nouvelles formes de flexibilité en matière de défense', in Giuliano Amato, Hervé Bribosia and Bruno De Witte (eds), Genesis and Destiny of the European Constitution (Bruylant 2007) 835. See, for further details, the chapter by Koutrakos in this volume.

24 Those three terms are borrowed from More Union in European Defence, Report of a CEPS Task Force, February 2015, p. 7.

25 See Benoit Gomis, 'Franco-British Defence and Security Treaties: Entente While it Lasts?', Chatham House Programme Paper ISP PP 2001/01, March 2011.

26 See, for a detailed discussion, the contributions by Herrmann and Van den Bogaert/Borger to this volume.

27 See the chapter by Ferran in this volume. 


\section{DIFFERENTIATION THROUGH INSTITUTIONAL PRACTICE}

\subsection{Secondary EU Law: Derogations, Formal and Informal Flexibility}

The oldest form of differentiation in EU law is still ubiquitous today: EU legislation adopted with the participation of all the Member States may allow individual states (whether named or not) to opt out from some of its provisions. This practice is linked to the processes of consensus building in the Council and compromise building between the Council and the Parliament under the codecision procedure. Often, this search for consensus and compromise is considered to allow for two routes: either a general agreement on a lowest common denominator norm or a decision to set a higher standard while allowing some states to derogate from it. There are many examples of the latter approach, some of which are mentioned in the chapters by Kingston and by Vos and Weimer in this volume. A further example is the Working Time Directive, which set some quite ambitious norms of social protection, but the price to be paid for this was the enactment of a series of derogatory clauses; in fact, half of the text of this directive is devoted to the definition of those derogations. ${ }^{28}$

In addition, we also find a large number of EU legal instruments intended from the outset, and deliberately, to apply only to a limited set of Member States. Sometimes those states are not named, although their identity is clear from the political context. A recent example is the Council Regulation of 15 March 2016 on emergency support within the EU. ${ }^{29}$ Although no specific Member State is named, either in the text of the regulation or in its preamble, it is clear to all that this measure was adopted so as to create a basis for channeling humanitarian assistance to Greece to deal with the massive influx of migrants and refugees in that country. In other cases, the beneficiary countries are spelled out. Recent examples, also from the domain of migration and asylum policy, are the two Council decisions of 2015 on the relocation of asylum seekers from Greece and Italy. ${ }^{30}$ In some policy areas, country-specific measures are ubiquitous and outnumber the acts with general territorial application.

28 On this directive, see the chapter by Dawson and Durana in this volume.

29 Council Regulation 2016/369 of 15 March 2016 on the provision of emergency support within the Union, OJ 2016, L70/1.

30 Council Decision 2015/1523 of 14 September 2015 establishing provisional measures in the area of international protection for the benefit of Italy and of Greece, OJ 2015, L239/146; Council Decision 2015/1601 of 22 September 
This is the case in macro-economic and fiscal governance, where the EU institutions adopt a myriad of decisions and recommendations addressed to individual countries, sometimes with major implications for their domestic policies. ${ }^{31}$

This phenomenon of territorial differentiation in EU legislation has become so common that one tends to forget how typical it is for the EU legal order; such frequent renunciation to the uniform application of common norms is rare in unitary states and even in federal states.

\subsection{Decline and Revival of Inter Se Agreements}

In contrast to differentiation in EU secondary legislation, flexibility is also occasionally sought through the intergovernmental cooperation of groups of Member States outside the EU legal order. This form of flexibility has existed since the early days of the European integration process. Indeed, it was clear from the outset, in the 1950s, that the new Community institutions would not provide the exclusive framework for the relations between the (then) six Member States. The EEC Treaty did not terminate any of the existing bilateral or multilateral treaties between them. During the negotiation of the EEC Treaty, and in the period immediately afterwards, several inter se agreements ${ }^{32}$ were concluded, also on matters related to those covered by the EEC Treaty; a prominent example was the Treaty establishing the Benelux Economic Union which was concluded on 3 February 1958, that is, only one month after the entry into force of the EEC Treaty. In anticipation of this, Article 233 EC stated - and Article 350 TFEU still states today - that the Treaty does not preclude 'the existence or completion of regional unions between Belgium and Luxembourg, or between Belgium, Luxembourg and the Netherlands ...'.

Benelux cooperation was not the only form of international cooperation between small groups of states. We can find numerous examples of international agreements concluded between Member States

establishing provisional measures in the area of international protection for the benefit of Italy and of Greece, OJ 2015, L248/80.

31 As for example the Council Implementing Decision 2015/1411 of 19 August 2015 approving the macroeconomic adjustment programme of Greece OJ 2015, L219/12.

32 I use the term 'inter se agreements' as a synonym for agreements concluded between less than all the Member States of the EC/EU. The term is traditionally used in international law for agreements concluded between some, but not all, parties to an earlier agreement. 
of the Community and the Union, ever since the 1950s, in areas such as tax law, environmental protection, defence, culture, and education. Such inter se agreements could also serve the purpose of allowing a group of Member States to move European integration forward in the face of the opposition of other Member States. One clear pre-Maastricht example of such a 'pioneer group initiative' was the Schengen cooperation regime, composed of a first Agreement signed in 1985, an implementing Convention adopted in 1990, and numerous specific decisions adopted by the Schengen Executive Committee after that. Schengen cooperation was started at a time when a general consensus on abolishing the controls on persons at the intra-Community borders could not be reached. The same reasons which justified the rule of Article 233 EEC Treaty, whereby the Benelux countries were allowed to adopt more advanced measures of integration, could be applied to Schengen. Yet, from the start, there was a concern that Schengen could develop from a transitional laboratory into a stable institutional regime functioning alongside the $\mathrm{EU}$ in a durable fashion, which seemed unattractive due to its important deficits in terms of transparency and judicial protection and also due to its proximity, content-wise, to the core idea of the internal market. The Schengen experiment therefore focused the minds of Europe's institutions and governments on how to institutionalize closer cooperation within rather than outside the main legal framework of the founding Treaties. The fact that the Amsterdam Treaty managed to terminate the separate legal life of the Schengen Agreement and Convention, by transforming their content into EU law, and that it had also established a system of enhanced cooperation within the EU institutional framework, could be seen as relegating inter se agreements to the margins of the European integration story. That impression could be reinforced by the fact that the Lisbon Treaty deleted some existing Treaty provisions which had previously invited the EU Member States to conclude international conventions among themselves to help advance the EU's integration agenda (former Articles 293 EC and 34(2)(d) EU).

Yet, the post-Lisbon practice shows that the EU Member States consider that they have retained the capacity and the right to conclude international treaties among themselves, even when the subject matter of their agreement is closely connected to EU policies. The conclusion of the 'Fiscal Compact' between 25 Member States and of the Treaty establishing the European Stability Mechanism between the then 17 euro-area states are recent and spectacular examples of the use of 
international law as a mechanism of differentiated integration. ${ }^{33}$ They were followed more recently (in May 2014) by the signature of yet another international agreement in the sphere of EMU law, namely the Agreement on the Single Resolution Fund, which is the intergovernmental part of the banking union package. ${ }^{34}$ This Agreement was signed by 26 Member States (all except the UK and Sweden) and entered into force on 1 January 2016. The original Commission proposal for a Europe-wide banking resolution mechanism was split in two by the Council, with one part (the resolution mechanism itself) forming the object of an EU regulation, whereas the other part (the building of a fund to be used for resolution operations) was left to be created by the Member States by means of a separate international agreement. This split was requested by Germany for a mixture of legal and political reasons which were not explained in a transparent way, ${ }^{35}$ and it has been criticized in the literature. ${ }^{36}$

33 On the political and legal circumstances explaining this recourse to extra-EU international agreements in the context of the euro crisis, see Bruno De Witte, 'Using International Law in the Euro Crisis - Causes and Consequences', ARENA Working Paper No. 4 (2013), http://www.sv.uio.no/arena/english/ research/publications/arena-publications/workingpapers/working-papers2013/wp413.pdf; among the many critical assessments, highlighting the threat to the EU's institutional integrity, see Angelos Dimopoulos, 'The Use of International Law as a Tool for Enhancing Governance in the Eurozone and its Impact on EU Institutional Integrity', in Maurice Adams, Federico Fabbrini and Pierre Larouche (eds), The Constitutionalization of European Budgetary Constraints (Hart 2014), 41.

34 Agreement on the Transfer and Mutualisation of Contributions to the Single Resolution Fund, [2014] Council doc. 8457/14.

35 In its press release on the day of the signature of the agreement, the Council enigmatically stated that 'using an intergovernmental agreement to establish rules on the transfer and mutualisation of contributions is intended to provide maximum legal certainty. The Council decided on this approach in December [2013], given legal and constitutional concerns in certain member states'. Council press release, Member States sign agreement on bank resolution fund, [2014] 10088/14. For some clarification of those 'concerns', see Alberto de Gregorio Merino, 'Reflexiones preliminares sobre la unión bancaria', (2014) 33 Revista General de Derecho Europeo 1, 7-8.

36 See the critical discussion of the Agreement: Federico Fabbrini, 'On Banks, Courts and International Law - The Intergovernmental Agreement on the Single Resolution Fund in Context' (2014) 21 Maastricht Journal of European and Comparative Law 444; see also Jean-Victor Louis, 'La difficile naissance du mécanisme européen de résolution des banques' (2014) Cahiers de droit européen 7. 
A further international agreement closely connected with the functioning of the EU, but in a very different domain, was signed on 19 February 2013 between 25 Member States (all except Croatia, Poland and Spain), namely the Agreement on a Unified Patent Court. ${ }^{37}$ That court's main task is to adjudicate an EU law instrument, namely the Regulation on the creation of unitary patent protection, which is itself, as mentioned above, the outcome of an enhanced cooperation initiative. There was no legal reason why this adjudication task could not have been entrusted to the Court of Justice (or a newly created specialized intellectual property court within it), but the 'patent community' apparently persuaded the Member State governments that it would be preferable to create a separate and allegedly more expert court instead. ${ }^{38}$ The Agreement on the Unified Patent Court will enter into force as soon as it is ratified by 13 of its Contracting Parties, ${ }^{39}$ which will lead to a curious case of 'enhanced cooperation within enhanced cooperation':40 25 out of the 28 Member States are bound by the patent regulation, but a smaller number of those could end up participating in the adjudication mechanism of that regulation, depending on whether or not they will ratify the Agreement.

\section{CONCLUSION: TOOLS OF FLEXIBILITY OR SEEDS OF DISINTEGRATION?}

The existence of a controlled system for differentiation between Member States has now become a stable characteristic of EU law. As rightly noted by Rosas and Armati, it is 'one of the defining features of the EU, setting it apart from established nation states. It is crucial to a description of

37 Agreement on a Unified Patent Court, OJ 2013, C175/1. For a discussion of the very idiosyncratic nature of this (still to be created) international court, see Manuel Desantes Real, 'Le paquet européen des brevets, paradigme du chemin à rebours: de la logique institutionnelle à la logique intergouvernementale' (2013) Cahiers de droit européen 577, 654-61; and Franklin Dehousse, 'La juridiction unifiée du brevet: le nouvel oxymoron du droit européen', in Inge Govaere et al (eds), The European Union in the World. Essays in Honour of Marc Maresceau (Brill 2014) 259.

38 See Dehousse (n. 37) 269.

39 Article 89(1) of the Agreement. Those 13 states must include Germany, France and the UK, which is yet another form of status differentiation between EU Member States. Those three countries are coyly referred to, in the Article, as 'the three Member States in which the highest number of European patents' have effect.

40 Desantes Real (n. 37), 641. 
what the Union legal order is' ${ }^{41}$ Although it has rightly been observed that territorial differentiation is more prevalent in what used to be 'core state powers', namely money, migration, criminal law, and defence, ${ }^{42}$ forms of flexibility have also spread into more traditional areas of EU competence, such as internal market law. Nor is the commonly used term of 'multi-speed integration' appropriate any more, in view of the fact that the Member States have ceased to pursue common goals at a different pace. Rather, they have fundamentally different views of the appropriate degree and scope of integration, and these different views are considered by the others to be both legitimate and durable.

Indeed, each of the elements of the flexibility design seems likely to last and to flourish. First, there is no reason to think that the major opt-out areas, namely EMU, immigration and criminal law, will become more uniform any time soon. In addition, now that enhanced cooperation has been experimented with a few times, one can expect it to become a more regularly used instrument in the EU's law-making toolbox, in particular in order to circumvent single country veto positions in policy matters where the unanimity rule applies. Thirdly, recourse to international agreements between groups of Member States outside the EU legal framework has been confirmed to be a valid option, particularly through its use in the context of the euro crisis, with the adoption of the ESM treaty and Fiscal Compact. Finally, we might see a continued and increasing use of the omnipresent micro-flexibility that has been part of Community law for decades, namely the recourse to minimum harmonization, to soft law and to tailor-made derogations. ${ }^{43}$

41 Allan Rosas and Lorna Armati, EU Constitutional Law: An Introduction (Hart Publishing 2010) 98. Similarly, for the author of a recent Italian textbook of EU law, variable geometry has become one of the three fundamental characteristics of the EU legal order: Jacques Ziller, Diritto delle politiche e delle istituzioni dell'Unione europea (Il Mulino 2013) $283 \mathrm{ff}$.

42 Berthold Rittberger, Dirk Leuffen and Frank Schimmelfennig, 'Differentiated Integration of Core State Powers', in Philipp Genschel and Markus Jachtenfuchs (eds), Beyond the Regulatory Polity? The European Integration of Core State Powers (Oxford University Press 2014) 189.

43 For an earlier discussion of this kind of differentiation in secondary EU law, see e.g. Gráinne de Búrca, 'Differentiation within the "Core"? The Case of the Internal Market' in Gráinne de Búrca and Joanne Scott (eds), Constitutional Change in the EU - From Uniformity to Flexibility? (Hart Publishing 2000) 133 and Ellen Vos, 'Differentiation, Harmonisation and Governance' in Bruno De Witte, Dominik Hanf and Ellen Vos (eds), The Many Faces of Differentiation in EU Law (Intersentia 2001) 145. 
As a result, the contours of the EU legal order have become rather fuzzy. In principle, there are firm criteria to determine whether a legal norm belongs to the EU legal order or not. Thus, measures of enhanced cooperation are part of EU law, although they are binding only upon, and within, the Member States that participated in their adoption. Similarly, legal measures from which some countries opt out are also part of the EU legal order, despite their limited geographical scope. Also, what is still called 'Schengen law' colloquially has become regular EU law after the incorporation of the Schengen regime in Amsterdam. On the contrary, international agreements concluded by a limited set of Member States (such as the ESM treaty and the Fiscal Compact) are not part of the EU legal order, and the Court of Justice cannot review the decisions adopted by organs set up under such an agreement. However, the institutional practice has led to a number of intertwinements between organs and legal norms of EU law and non-EU law. Examples of this fuzziness are the fact that EU institutions are being 'borrowed' by the Member States when setting up and operating an inter se regime, as is the case with the European Stability Mechanism; ${ }^{44}$ and the fact that the entry into force of norms of secondary EU law is conditioned on the prior entry into force of a satellite agreement, as we have seen in recent years with the unified patent regime and the banking resolution mechanism.

If the formal criteria for deciding what belongs to the EU legal order still function well, the content of that EU legal order presents a very unusual shape. Its degree of fragmentation, in terms of the participation of states in decision-making and of the applicability of legal norms across the EU territory, is rather unique and sets the EU firmly apart from the federal constitutional systems which it resembles in other respects. The Court's old ideal of EU legal rules being 'fully applicable at the same time and with identical effects over the whole territory of the Community' 45 has become unattainable. This, in itself, may not be such a great loss; but the easy and almost insouciant recourse to variable geometry also comes with a lack of transparency, complicated accountability mechanisms, and a neglect of intra-state solidarity, and these are

44 This 'borrowing' of the EU institutions to accomplish non-EU tasks is legally controversial. See discussion by Paul Craig, 'Pringle and Use of EU Institutions outside the EU Legal Framework: Foundations, Procedure and Substance' (2013) 9 European Constitutional Law Review 273; and Steve Peers, 'Towards a New Form of EU Law? The Use of EU Institutions outside the EU Legal Framework' (2013) 9 European Constitutional Law Review 37.

45 See the citation from Commission $v$ Italy in the introduction of this chapter. 
serious challenges for the constitutional integrity of the EU. There is thus a danger that the mechanisms of differentiation, rather than serving as useful instruments of flexibility, may turn into contributory factors in the disintegration of the EU.

\section{REFERENCES}

Beach D, The Dynamics of European Integration: Why and When EU Institutions Matter (Palgrave Macmillan 2005).

Bosse-Platière I, 'Annexes aux Traités européens et différenciation', in Barbou des Places S (ed.), Aux marges du traité: déclarations, protocoles et annexes aux traités européens (Bruylant 2011) 115-32.

Bribosia $\mathrm{H}$, 'Les nouvelles formes de flexibilité en matière de défense', in Amato G, Bribosia H and De Witte B (eds), Genesis and Destiny of the European Constitution (Bruylant 2007) 835.

Craig P, 'Pringle and Use of EU Institutions outside the EU Legal Framework: Foundations, Procedure and Substance' (2013) 9 European Constitutional Law Review 2, 263-84.

Cremona M, 'Enhanced Cooperation and the Common Foreign and Security and Defence Policy' (2009) EUI Working Papers LAW 2009/21.

Curtin D, 'The Constitutional Structure of the Union: A Europe of Bits and Pieces' (1993) 30 Common Market Law Review 1, 17-69.

De Búrca G, 'Differentiation within the "Core"? The Case of the Internal Market' in De Búrca G and Scott J (eds), Constitutional Change in the EU From Uniformity to Flexibility? (Hart Publishing 2000) 133-72.

De Gregorio Merino A, 'Reflexiones preliminares sobre la unión bancaria' (2014) 33 Revista General de Derecho Europeo 1, 7-8.

Dehousse F, 'La juridiction unifiée du brevet: le nouvel oxymoron du droit européen', in Inge Govaere et al (eds), The European Union in the World. Essays in Honour of Marc Maresceau (Brill 2014) 259-74.

Desantes Real M, 'Le paquet européen des brevets, paradigme du chemin à rebours: de la logique institutionnelle à la logique intergouvernementale' (2013) 49 Cahiers de droit européen 3, 577-670.

De Witte B, 'Using International Law in the Euro Crisis - Causes and Consequences', ARENA Working Paper No. 4 (2013), http://www.sv.uio.no/ arena/english/research/publications/arena-publications/workingpapers/workingpapers2013/wp4-13.pdf.

Dimopoulos A, 'The Use of International Law as a Tool for Enhancing Governance in the Eurozone and its Impact on EU Institutional Integrity', in Adams M, Fabbrini F and Larouche P (eds), The Constitutionalization of European Budgetary Constraints (Hart 2014) 41-64.

Fabbrini F, 'On Banks, Courts and International Law - The Intergovernmental Agreement on the Single Resolution Fund in Context' (2014) 21 Maastricht Journal of European and Comparative Law 3, 444-63.

Gaja G, 'How Flexible is Flexibility under the Amsterdam Treaty?' (1998) 35 Common Market Law Review 4, 855-70. 
Gomis B, 'Franco-British Defence and Security Treaties: Entente While it Lasts?', Chatham House Programme Paper ISP PP 2001/01, March 2011.

Kortenberg H [a pseudonym], 'Closer Cooperation in the Treaty of Amsterdam' (1998) 35 Common Market Law Review 4, 833-54.

Louis Jean-Victor, 'La difficile naissance du mécanisme européen de résolution des banques' (2014) 50 Cahiers de droit européen 1, 7-20.

Maganza G, 'Jean-Claude Piris, un seul homme pour cinq traités' in A Man for all Treaties - Liber Amicorum en l'honneur de Jean-Claude Piris (Bruylant 2012) 399-420.

Major J, 'Europe, A Future that Works' (William and Mary Lecture, Leiden Town Hall), Agence Europe, No 6312, 10 September 1994.

Monar J, 'Justice and Home Affairs in the Treaty of Amsterdam: Reform at the Price of Fragmentation' (1998) 23 European Law Review, 320-26.

Papagianni G, 'Flexibility in Justice and Home Affairs: An Old Phenomenon Taking New Forms' in De Witte B, Hanf D and Vos E (eds), The Many Faces of Differentiation in EU Law (Intersentia 2001) 101-28.

Peers S, 'Towards a New Form of EU Law? The Use of EU Institutions outside the EU Legal Framework' (2013) 9 European Constitutional Law Review 1, $37-72$.

Peers S, 'The UK Opts back in to the European Arrest Warrant - and other EU Criminal Law' (2014) EU Law Analysis, http://eulawanalysis.blogspot.co.uk.

Phinnemore D, The Treaty of Lisbon - Origins and Negotiation (Palgrave Macmillan 2013).

Rittberger B, Leuffen D and Schimmelfennig F, 'Differentiated Integration of Core State Powers', in Genschel P and Jachtenfuchs M (eds), Beyond the Regulatory Polity? The European Integration of Core State Powers (Oxford University Press 2014) 189-210.

Rosas A and Armati L, EU Constitutional Law: An Introduction (Hart Publishing 2010).

Schutte J, 'UK v EU: A Continuous Test Match' (2011) 34 Fordham International Law Journal 1346-1376.

Stubb A, Negotiating Flexibility in the European Union. Amsterdam, Nice and Beyond (Palgrave Macmillan 2002).

Vos E, 'Differentiation, Harmonisation and Governance' in De Witte B, Hanf D and Vos E (eds), The Many Faces of Differentiation in EU Law (Intersentia 2001) 145-79.

Ziller J, Diritto delle politiche e delle istituzioni dell'Unione europea (Il Mulino 2013). 